\title{
Katekolaminerg polymorf ventrikkeltakykardi
}

\begin{abstract}
Sammendrag
Bakgrunn. Katekolaminerg polymorf ventrikkeltakykardi karakteriseres av synkoper og hjertestans og ble beskrevet klinisk første gang i 1975. Senere har man kartlagt at dette er en arvelig hjertesykdom med risiko for livstruende arytmier. Som oftest skyldes den mutasjoner i ryanodinreseptor 2-genet. Med utgangspunkt i en kasuistikk presenteres her en oversikt over katekolaminerg polymorf ventrikkeltakykardi.
\end{abstract}

Materiale og metode. Kunnskapsgrunnlaget er et ikke-systematisk søk i PubMed.

Resultater. Normalt EKG i hvile gjør at tilstanden lett overses, og synkopene kan forveksles med epilepsi. Synkopenes relasjon til fysisk og psykisk stress samt en anamnese med plutselige dødsfall og uforklarte synkoper i familien er sentrale diagnostiske elementer. Arbeids-EKG viser ofte hyppige ventrikulære ekstrasystoler ved puls over 100 slag per minutt. Diagnosen kan verifiseres ved gentesting. Ved behandling med betablokker og eventuelt implanterbar defibrillator bedres leveutsiktene.

Fortolkning. Katekolaminerg polymorf ventrikkeltakykardi er en alvorlig sykdom, og ubehandlet er prognosen dårlig. Hos unge med synkoper eller hjertestans er sykdommen en viktig differensialdiagnose. Gentest gir mulighet for å oppdage mutasjonsbærere i familien slik at forebyggende tiltak kan iverksettes hos slektninger med økt risiko for kardiale hendelser.

\section{Ida Skrinde Leren}

Det medisinske fakultet

Universitetet i Oslo

\section{Kristina Hermann Haugaa}

kristina.haugaa@rr-research.no

Thor Edvardsen

Hjertemedisinsk avdeling

Oslo universitetssykehus, Rikshospitalet 0027 Oslo

og

Universitetet i Oslo

\section{Ole-Gunnar Anfinsen}

\section{Erik Kongsgård}

Hjertemedisinsk avdeling

Oslo universitetssykehus, Rikshospitalet

\section{Knut Erik Berge}

Trond P. Leren

Medisinsk genetisk laboratorium

Avdeling for medisinsk genetikk

Oslo universitetssykehus, Rikshospitalet

\section{Jan P. Amlie}

Medisinsk poliklinikk

Oslo universitetssykehus, Rikshospitalet og

Universitetet i Oslo

Et plutselig dødsfall er alltid dramatisk, særlig når det dreier seg om unge mennesker. I $10-20 \%$ av tilfellene finner man ingen forklaring, selv etter obduksjon (1). Arvelige kardiale arytmogene tilstander kan da være én mulig årsak, og disse antas å forklare omtrent en tredel av uforklarte dødsfall hos barn og unge (2). Flere av de arvelige arytmogene sykdommene er tidligere beskrevet i Tidsskriftet (3). $14 \%$ av plutselige, uventede dødsfall kan skyldes katekolaminerg polymorf ventrikkeltakykardi (CPVT) (2). Dette er en relativt nyoppdaget og lite kjent tilstand, men den er en mulig årsak til synkoper og plutselig død hos yngre mennesker. Vi vil på bakgrunn av en kasuistikk gi en oversikt over sykdommen.

\section{Materiale og metode}

Litteratur om katekolaminerg polymorf ventrikkeltakykardi er fremskaffet gjennom et ikke-systematisk søk i PubMed.

\section{Historikk}

Stressutløst bidireksjonal ventrikkeltakykardi hos barn ble beskrevet både i 1962 (4) og i 1975 (5), men betegnelsen «katekolaminerg polymorf ventrikkeltakykardi» ble brukt først i 1995 (6). I 2001 kunne man vise at den autosomalt dominante arvelige formen skyldtes en mutasjon i genet for den kardiale ryanodinreseptor 2 (RyR2) (7). Samme år viste Lahat og medarbeidere (8) at en mutasjon i genet for calsequestrin 2 var årsaken til en svært sjelden autosomalt recessiv form.

\section{Kasuistikk}

Pasienten. En 13 år gammel gutt ble innlagt i sykehus etter en nærdrukningsepisode han hadde besvimt under kappsvømming. Foreldrene fortalte at han tidligere hadde hatt fem synkoper, alle anstrengelsesutløst. I tillegg hadde han hatt flere episoder med svimmelhet og uvelhet ved aktivitet. Under utredningen ble det utført hvile-EKG, ekkokardiografi, MR cor, koronar angiografi og elektrofysiologisk undersøkelse inkludert provokasjon med ajmalin (korttidsvirkende klasse (c-antiarytmikum), alle med normale funn. Arbeids-EKG viste ventrikulære ekstrasystoler i bigemini og i par ved belastning. Det ble startet med betablokker. Gentest av RyR2-genet viste en mutasjon. Pasienten har vært symptomfri etter opptrapping til maksimal tolerert betablokkerdose. Hans mor var mutasjonsbærer og hadde hatt gjentatte synkoper i barne- og ungdomsalder, særlig $i$ forbindelse med svømming. Hun hadde fått diagnosen epilepsi og var blitt behandlet for dette. Etter påvist RyR2-mutasjon har hun fått behandling med betablokker og har vært symptomfri.

\section{Patogenese og genetikk}

Katekolaminerg polymorf ventrikkeltakykardi er definert som ventrikkeltakykardi indusert ved fysisk anstrengelse eller katekolamininfusjon og med mer enn to forskjellige morfologier på EKG. I tillegg skal det være fravær av elektrolyttforstyrrelser,

\section{Hovedbudskap}

- Katekolaminerg polymorf ventrikkeltakykardi er en viktig differensialdiagnose ved synkope hos barn og ungdom

- Fysisk og psykisk stress, særlig svømming, er typiske arytmitriggere

- Ved arbeids-EKG påvises hyppige ventrikulære ekstrasystoler ved økende belastning

- Diagnosen kan bekreftes ved gentest

- Standardbehandlingen er betablokkere og eventuelt implanterbar defibrillator 
medikamentbruk, strukturell hjertesykdom eller annen primær elektrofysiologisk sykdom som kan forklare funnene (9).

I de fleste tilfeller er katekolaminerg polymorf ventrikkeltakykardi et resultat av en RyR2-defekt. RyR2 er sentral i den intracellulære kalsiumfrigjøringen fra sarkoplasmatisk retikulum (10) (fig 1). Defekt funksjon av denne reseptoren fører til økt konsentrasjon av kalsium i cytosol, noe som kan gi opphav til sene etterdepolariseringer (11) (fig 2). Sene etterdepolariseringer er en patologisk økning av membranpotensialet i diastolen som kan utløse maligne arytmier. RyR2 påvirkes av katekolaminer som frigjøres ved både fysisk og psykisk stress, og først ved slik provokasjon får defekten funksjonelle konsekvenser. Feilfunksjon i calsequestrin 2, som normalt bufrer kalsium i sarkoplasmatisk retikulum, gir et liknende bilde (10).

Den vanligste formen for katekolaminerg polymorf ventrikkeltakykardi er autosomalt dominant arvelig og skyldes mutasjoner i RyR2-genet. Det er angitt at man kan påvise en slik mutasjon hos $18-75 \%$ av dem med klinisk sykdom (10). Variasjonene i angivelsene kan forklares med at $R y R 2$-genet er et av organismens største og inneholder hele 105 eksoner (12). Av kostnadshensyn er det derfor i praksis svært sjelden at alle eksonene sekvenseres. Det er også mulig at det finnes andre, foreløpig ukjente gener der mutasjoner kan gi opphav til samme tilstand. Penetransen er angitt til å være ca. 70-80\% (10). En del av mutasjonene i RyR2-genet oppstår de novo, det vil si at de ikke er arvet fra noen av foreldrene $(6,7)$. I svært sjeldne tilfeller finner man en autosomalt recessiv form for katekolaminerg polymorf ventrikkeltakykardi forårsaket av mutasjoner i calsequestrin 2-genet (13).

\section{Symptomer}

Karakteristisk for tilstanden er anstrengelses- eller emosjonsutløste synkoper i ung alder forårsaket av ventrikkeltakykardi. Ventrikkeltakykardien kan degenerere til ventrikkelflimmer, og plutselig død kan være første manifestasjon av sykdommen (10). Hyppige spredte ventrikulære ekstrasystoler eller ventrikulære ekstrasystoler i bigemini kan gi svimmelhet og hjertebank. Alt slags fysisk og psykisk stress kan utløse arytmiene.

Som hos pasienter med lang QT-tid-syndrom er svømming en typisk utløsende faktor (14). Man antar at kombinasjonen av fysisk aktivitet, voluntær apné og eventuelt kaldt vann gir en koaktivering av sympatikus og parasympatikus, som igjen bidrar til $ø k t$ frigjøring av katekolaminer og dermed gir arytmitendens $(15,16)$. Man bør vurdere katekolaminerg polymorf ventrikkeltakykardi som mulig årsak ved drukning eller nærdrukning hos svømmedyktige barn og ungdommer.

Oftest debuterer katekolaminerg polymorf ventrikkeltakykardi i barneårene eller tidlige ungdomsår. Gjennomsnittsalderen er $7-9$ år $(17,18)$. Det er så langt ikke rappor- tert om noen tilfeller blant spedbarn, og man har spekulert i om aktivitetsnivået ikke er tilstrekkelig høyt hos dem (9). Siden katekolaminerg polymorf ventrikkeltakykardi er en relativt nyoppdaget tilstand, er imidlertid forekomsten hos spedbarn lite undersøkt. Katekolaminerg polymorf ventrikkeltakykardi kan derfor være en av flere årsaker til plutselig, uventet spedbarnsdød. Det er angitt at sykdomsdebut $\mathrm{i}$ voksen alder er sjeldent (9).

\section{Prognose}

Katekolaminerg polymorf ventrikkeltakykardi er en alvorlig sykdom. Ca. $80 \%$ av pasientene opplever en kardial hendelse før de har fylt 40 år (19). Pasienter med symptomer har ubehandlet en mortalitet på ca. $30 \%$ innen fylte 30 år (20). Selv om de fleste diagnostiseres i barne- og ungdomsårene, kan første alvorlige hendelse komme i voksen alder, noe som understreker viktigheten av langvarig oppfølging og eventuell dosejustering av betablokker (21).

\section{Diagnose}

Anamnesen spiller en nøkkelrolle i utredningen. Relasjonen mellom synkopene og fysisk aktivitet eller stress er viktig å få frem. Familieanamnesen bør innbefatte spørsmål om eventuelle plutselige dødsfall i familien og uforklarte synkoper. Rundt $30 \%$ av pasientene har en positiv slektshistorie for slike hendelser (6).

Det er vanligvis normale funn ved klinisk undersøkelse, hvile-EKG, ekkokardiografi og elektrofysiologisk undersøkelse, og diagnosen kan derfor lett overses. Noen studier har vist at pasienter med katekolaminerg polymorf ventrikkeltakykardi har sinusbradykardi $(9,17,18)$ og prominente U-bølger i hvile-EKG $(22,23)$, men det er ingen generell enighet om dette (19). Den beste kliniske diagnostiske testen er arbeids-EKG, hvor man i nesten alle tilfeller vil kunne fremkalle spredte ventrikulære ekstrasystoler, ventrikulære ekstrasystoler i bigemini eller i par, bidireksjonal eller polymorf ventrikkeltakykardi og ventrikkelflimmer $(9,19,24)$. Bidireksjonal ventrikkeltakykardi kjennetegnes av at R-bølgeaksen roterer $180^{\circ}$ fra slag til slag (6) (fig 3) og er et typisk funn hos pasientene. Bidireksjonal ventrikkeltakykardi ses også ved digitalisintoksikasjon og hjertesvikt, begge tilstander med økt intracellulær kalsiumkonsentrasjon $(25,26)$.

Arytmiene ved arbeids-EKG tiltar vanligvis i alvorlighetsgrad jo mer uttalt anstrengelsen er. Ekstrasystolene opptrer typisk ved en hjertefrekvens på rundt 110-130 slag per minutt, og er påfallende reproduserbare (19, 27). En ventrikkeltakykardi under arbeidsbelastning vil kunne degenerere til ventrikkelflimmer, og arbeids-EKG må derfor utføres med defibrilleringsberedskap (19). Arytmiene kan også oppdages under Holtermonitorering, spesielt hos dem der arytmi- 
ene i hovedsak er utløst av emosjonelt stress (19).

Diagnosen katekolaminerg polymorf ventrikkeltakykardi kan verifiseres ved hjelp av genteknologi, der man påviser en mutasjon i RyR2-genet. Dersom det ikke påvises noen arytmi ved arbeids-EKG og gentesten er negativ, men man fortsatt har mistanke om katekolaminerg polymorf ventrikkeltakykardi, er en implanterbar rytmeovervåker en mulighet for å påvise arytmier. Postmortemanalyser med mutasjonsutredning er aktuelt ved plutselig, uventet dødsfall hos barn og unge der det ikke påvises noen dødsårsak ved obduksjon. Dette kan være viktig for å få en forklaring på dødsfallet og for å oppdage andre familiemedlemmer som kan være utsatt for alvorlig arytmi.

Viktige differensialdiagnoser er vasovagal synkope, epilepsi, hypertrofisk kardiomyopati, arytmogen høyre ventrikkelkardiomyopati, lang QT-tid-syndrom, Andersen-Tawils syndrom og Brugadas syndrom (28). Undersøkelser som hvile-EKG, ekkokardiografi, vippetest, EEG og eventuelt elektrofysiologisk undersøkelse med flekainid-/ajmalintest kan være nyttige for videre avklaring.

\section{Prevalens}

Katekolaminerg polymorf ventrikkeltakykardi er en sjelden sykdom. Det knytter seg usikkerhet til prevalensen, men den har vært estimert så høyt som 1:10000 (27). Det største pasientmaterialet som er beskrevet $i$ litteraturen, omfatter 101 pasienter og pårørende (21). Ved Medisinsk genetisk laboratorium, Oslo universitetssykehus, Rikshospitalet, har man per mars 2009 påvist $R y R 2$ mutasjon som årsak til katekolaminerg polymorf ventrikkeltakykardi hos i underkant av 50 pasienter.

\section{Behandling}

Betablokkere er standardbehandling ved katekolaminerg polymorf ventrikkeltakykardi. Effektiviteten av denne behandlingen har imidlertid vært gjenstand for debatt. Leenhardt og medarbeidere (17) og Postma og medarbeidere (18) rapporterte om nesten $100 \%$ forebygging av kardiale hendelser ved god oppfølging og etterlevelse av betablokkerbehandlingen. Andre som har studert effekten av slik behandling, har vist at den ikke gir full beskyttelse - verken mot synkoper, dødsfall eller mer uskyldige arytmier $(6,9)$. Selv under betablokkerbehandling har de fleste fortsatt enkelte ventrikulære ekstrasystoler ved fysisk aktivitet (17, 23, 29). Gode medikamentrutiner hos pasienten er avgjørende. Forglemmelse av én dose kan fremprovosere potensielt dødelige rytmeforstyrrelser (17).

Det er ingen internasjonal enighet angående hvilken type betablokker som skal brukes i behandlingen. Imidlertid har nyere studier indikert at nadolol, en ikke-selektiv betablokker uten intrinsisk sympatomimetisk
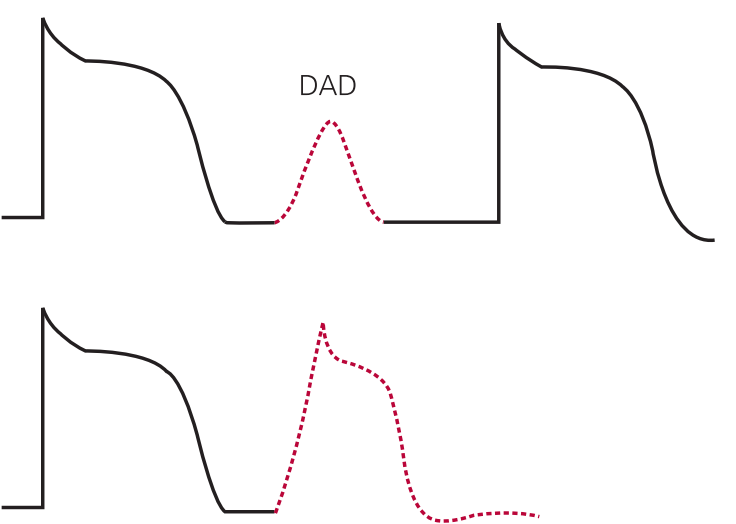

Figur 2 Sene etterdepolariseringer (delayed after depolarizations, DAD). Defekte ryanodinreseptorer kan føre til økt nivå av kalsium i cytosol og gi opphav til sene etterdepolariseringer. Sene etterdepolariseringer er en patologisk økning av membranpotensialet i diastolen. Hvis det økte membranpotensialet når over en terskelverdi, kan det utløse et nytt aksjonspotensial og trigge maligne ventrikkeltakykardier

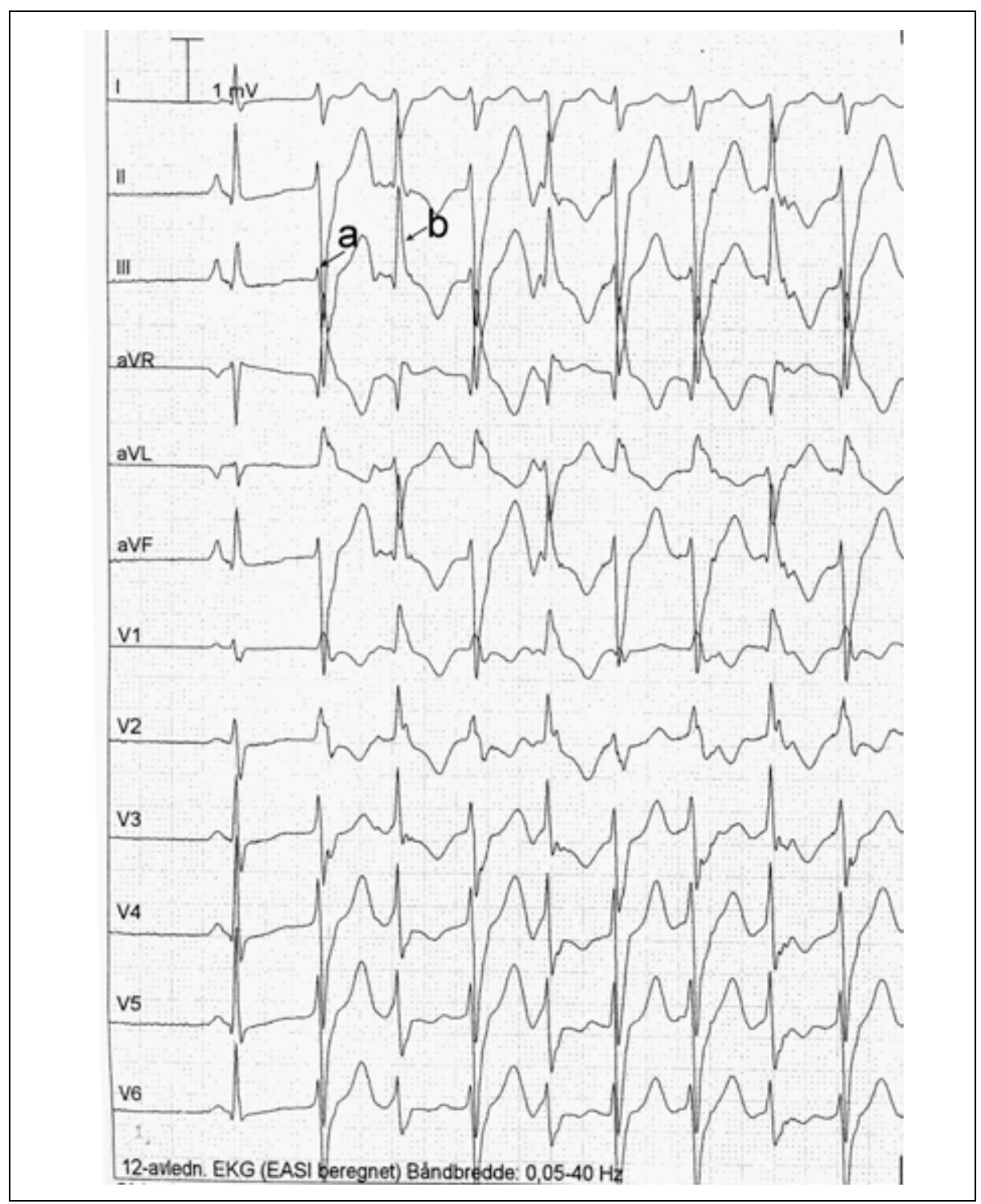

Figur 3 Bidireksjonal ventrikkeltakykardi kjennetegnes av at R-bølgeaksen roterer $180^{\circ}$ fra slag til slag. (R-bølgeaksen i slag a (pil) er $180^{\circ}$ motsatt fra slag b (pil).) Den utløses av økte intracellulære kalsiumkonsentrasjoner og forekommer foruten ved katekolaminerg polymorf ventrikkeltakykardi også ved digitalisintoksikasjon 
aktivitet, kan ha fordeler fremfor andre betablokkere i å forhindre kardiale hendelser hos dem med katekolaminerg polymorf ventrikkeltakykardi (21). Nadolol er ikke registrert i Norge, men kan søkes på registreringsfritak.

Det er blitt spekulert i hvorvidt man ved å legge til en kalsiumkanalblokker vil få bedre kontroll av arytmiene. Rasjonalet bak dette er at disse midlene reduserer amplituden av sene etterdepolariseringer og med det hindrer at det oppstår ventrikulære ekstrasystoler (30). Det er kun gjort to små studier på dette (med totalt 12 pasienter), men disse har vist god antiarytmisk effekt av kalsiumkanalblokkere $(30,31)$. Natriumkanalblokkere som disopyramid og mexiletin er blitt forsøkt brukt i en liten studie (9), men tre av fire i behandlingsgruppen døde plutselig. Dyreforsøksstudier har vist lovende resultater ved behandling med natriumkanalblokkeren flekainid (32). Tilførsel av magnesium har også vært forsøkt - uten overbevisende resultater (31).

Hos pasienter med synkoper eller alvorlige arytmier på tross av maksimal tolerert betablokkerdose eller på grunn av sviktende etterlevelse av medikamentell behandling er det indikasjon for implanterbar defibrillator (33). Maksimal betablokkerdose opprettholdes for å minimere antallet defibrilleringer. Hos pasienter med dårlig arytmikontroll og innslag av implanterbar defibrillator på tross av maksimal betablokkerdose kan kirurgisk sympatektomi vurderes (34). Overlevd hjertestans er en absolutt indikasjon for en implanterbar defibrillator.

Personer med katekolaminerg polymorf ventrikkeltakykardi bør ikke drive med konkurranseidrett (35), og de bør ikke bade alene.

\section{Konklusjon}

Hos unge mennesker med synkope eller hjertestans er katekolaminerg polymorf ventrikkeltakykardi en viktig differensialdiagnose. Normale funn ved hvile-EKG gjør at tilstanden er lett å overse, og den kan forveksles med epilepsi. Synkopenes relasjon til fysisk og psykisk stress, samt forekomst av plutselige dødsfall og uforklarte synkoper $\mathrm{i}$ familien, er viktig informasjon $\mathrm{i}$ den diagnostiske utredningen. Ved hjelp av arbeids-EKG kan man få mistanke om diagnosen, som kan verifiseres ved genetisk analyse. Ved behandling med betablokkere og eventuelt implantert defibrillator bedres prognosen. Genetisk analyse gir også mulighet for å oppdage mutasjonsbærere i familien slik at forebyggende tiltak kan iverksettes hos disse.

Pasienten og pasientens foresatte har gitt samtykke til at artikkelen blir publisert.

Oppgitte interessekonflikter: Ingen
Litteratur

1. Morentin B, Suarez-Mier MP, Aguilera B. Sudden unexplained death among persons $1-35$ years old. Forensic Sci Int 2003: 135: 213-7.

2. Tester DJ, Ackerman MJ. Cardiomyopathic and channelopathic causes of sudden unexplained death in infants and children. Annu Rev Med 2009; 60: $69-84$.

3. Haugaa KH, Berge KE, Fruh A et al. Kardiale kanalopatier - diagnostikk og behandling. Tidsskr Nor Lægeforen 2005; 125: 2778-81.

4. Horan M, Venables AW. Paroxysmal tachycardia with episodic unconsciousness. Arch Dis Child 1962; 37: 82-5.

5. Reid DS, Tynan M, Braidwood L et al. Bidirectiona tachycardia in a child. A study using His bundle electrography. Br Heart J 1975; 37: 339-44

6. Priori SG, Napolitano C, Memmi M et al. Clinical and molecular characterization of patients with catecholaminergic polymorphic ventricular tachycardia. Circulation 2002; 106: 69-74.

7. Priori SG, Napolitano C, Tiso N et al. Mutations in the cardiac ryanodine receptor gene (hRyR2) underlie catecholaminergic polymorphic ventricular tachycardia. Circulation 2001; 103: 196-200.

8. Lahat H, Pras E, Olender T et al. A missense mutation in a highly conserved region of CASQ2 is associated with autosomal recessive catecholamineinduced polymorphic ventricular tachycardia in Bedouin families from Israel. Am J Hum Genet 2001; 69: 1378-84

9. Sumitomo N, Harada K, Nagashima M et al. Catecholaminergic polymorphic ventricular tachycardia: electrocardiographic characteristics and optimal therapeutic strategies to prevent sudden death. Heart 2003; 89: 66-70.

10. Kontula K, Laitinen PJ, Lehtonen A et al. Catecholaminergic polymorphic ventricular tachycardia: recent mechanistic insights. Cardiovasc Res 2005; 67: 379-87.

11. Liu N, Priori SG. Disruption of calcium homeostasis and arrhythmogenesis induced by mutations in the cardiac ryanodine receptor and calsequestrin. Cardiovasc Res 2008; 77: 293-301.

12. Tiso N, Stephan DA, Nava A et al. Identification of mutations in the cardiac ryanodine receptor gene in families affected with arrhythmogenic right ventricular cardiomyopathy type 2 (ARVD2). Hum Mol Genet 2001; 10: 189-94.

13. Yano K, Zarain-Herzberg A. Sarcoplasmic reticulum calsequestrins: structural and functional properties. Mol Cell Biochem 1994; 135: 61-70.

14. Choi G, Kopplin LJ, Tester DJ et al. Spectrum and frequency of cardiac channel defects in swimming-triggered arrhythmia syndromes. Circulation 2004: 110: 2119-24.

15. Gooden BA. Mechanism of the human diving response. Integr Physiol Behav Sci 1994; 29: 6-16.

16. Marsh N, Askew D, Beer K et al. Relative contributions of voluntary apnoea, exposure to cold and face immersion in water to diving bradycardia in humans. Clin Exp Pharmacol Physiol 1995; 22: $886-7$.

17. Leenhardt A, Lucet V, Denjoy I et al. Catecholaminergic polymorphic ventricular tachycardia in children. A 7-year follow-up of 21 patients. Circulation 1995; 91: 1512-9.

18. Postma AV, Denjoy I, Kamblock J et al. Catecholaminergic polymorphic ventricular tachycardia: RYR2 mutations, bradycardia, and follow up of the patients. J Med Genet 2005; 42: 863-70.

19. Napolitano C, Priori SG. Diagnosis and treatment of catecholaminergic polymorphic ventricular tachycardia. Heart Rhythm 2007; 4: 675-8.

20. Swan H, Piippo K, Viitasalo M et al. Arrhythmic dis order mapped to chromosome 1q42-q43 causes malignant polymorphic ventricular tachycardia in structurally normal hearts. J Am Coll Cardiol 1999; 34: 2035-42.

21. Hayashi M, Denjoy I, Extramiana F et al. Incidence and risk factors of arrhythmic events in catecholaminergic polymorphic ventricular tachycardia. Circulation 2009: 119: 2426-34

22. Aizawa $Y$, Komura $S, O$ kada $S$ et al. Distinct $U$ wave changes in patients with catecholaminergic polymorphic ventricular tachycardia (CPVT). Int Heart J 2006; 47: 381-9.

23. Fisher JD, Krikler D, Hallidie-Smith KA. Familial polymorphic ventricular arrhythmias: a quarter century of successful medical treatment based on serial exercise-pharmacologic testing. J Am Coll Cardiol 1999; 34: 2015-22.

24. Celiker A, Erdogan I, Karagoz T et al. Clinical experiences of patients with catecholaminergic polymorphic ventricular tachycardia. Cardiol Young 2009; 19: 45-52.

25. Katz G, Arad M, Eldar M. Catecholaminergic polymorphic ventricular tachycardia from bedside to bench and beyond. Curr Probl Cardiol 2009; 34: $9-43$.

26. Liu N, Colombi B, Raytcheva-Buono EV et al. Catecholaminergic polymorphic ventricular tachycardia. Herz 2007; 32: 212-7.

27. Liu N, Ruan Y, Priori SG. Catecholaminergic polymorphic ventricular tachycardia. Prog Cardiovasc Dis 2008; 51: 23-30

28. Tester DJ, Ackerman M. Cardiomyopathic and channelopathic causes of sudden, unexpected death in infants and children. Annu Rev Med 2009. 60: 69-84

29. Swan H, Laitinen PJ. Familial polymorphic ventricular tachycardia -intracellular calcium channe disorder. Card Electrophysiol Rev 2002; 6: 81-7.

30. Rosso R, Kalman JM, Rogowski 0 et al. Calcium channel blockers and beta-blockers versus betablockers alone for preventing exercise-induced arrhythmias in catecholaminergic polymorphic ventricular tachycardia. Heart Rhythm 2007; 4 : $1149-54$

31. Swan H, Laitinen P, Kontula K et al. Calcium channel antagonism reduces exercise-induced ventricular arrhythmias in catecholaminergic polymorphic ventricular tachycardia patients with RyR2 mutations. J Cardiovasc Electrophysiol 2005; 16: $162-6$.

32. Watanabe H, Chopra N, Laver D et al. Flecainide prevents catecholaminergic polymorphic ventricular tachycardia in mice and humans. Nat Med 2009; 15: 380-3.

33. Epstein AE, DiMarco JP, Ellenbogen KA et al. ACC/ AHA/HRS 2008 Guidelines for device-based therapy of cardiac rhythm abnormalities: executive summary: a report of the American College of Cardiology/American Heart Association Task Force on Practice Guidelines. J Am Coll Cardiol 2008; 51: 2085-105.

34. Wilde AA, Bhuiyan ZA, Crotti L et al. Left cardiac sympathetic denervation for catecholaminergic polymorphic ventricular tachycardia. N Engl J Med 2008; 358: 2024-9.

35. Heidbuchel H, Corrado D, Biffi A et al. Recommendations for participation in leisure-time physical activity and competitive sports of patients with arrhythmias and potentially arrhythmogenic conditions. Part II: ventricular arrhythmias, channelopathies and implantable defibrillators. Eur J Cardiovasc Prev Rehabil 2006; 13: 676-86.

Manuskriptet ble mottatt 18.4. 2009 og godkjent 12.11. 2009. Medisinsk redaktør Åslaug Helland. 